\title{
RHIZOMATIC INFORMATICS: The Case of Ivy University
}

\author{
Chris Atkinson \\ Manchester Business School \\ University of Manchester \\ Manchester, England \\ Laurence Brooks \\ Department of Information Systems and Computing \\ Brunel University \\ Uxbridge, England
}

\begin{abstract}
While the debate over information systems and their role in society persists, the discipline continues to seek approaches to better understand IS, and its complex interactions with organizations and people. This paper draws ideas from Deleuze and Guattari's work on rhizomes (a nonhierarchical network) and its opposing tree (arboreal structure), to develop better insights (Deleuze and Guattari 2004). The paper specifically revisits the case of Ivy University, in which a major introduction of an ERP application was attempted by the powerful central administration. When this centralized and arboreal structure collapses, it is eventually replaced by a much more organic system, which emerged from the localized and ad hoc software developments that had already taken place. The rhizomic interpretation of this case enables both a conceptualization of information systems within social and organizational settings and offers a set of principles on which the concept of a "rhizomatic informatics" may be based and IS case studies interpreted.
\end{abstract}

Keywords Rhizomatics, arboreal, territorialization, nomad, ERP, case study

Please use the following format when citing this chapter:

Atkinson, C., and Brooks, L., 2008, in IFIP International Federation for Information Processing, Volume 267, Information Technology in the Service Economy: Challenges and Possibilities for the $21^{\text {st }}$ Century, eds. Barrett, M., Davidson, E., Middleton, C., and DeGross, J. (Boston: Springer), pp. 81-101. 


\section{INTRODUCTION}

Over the past 20 years, information systems research has drawn on a number of conceptual frameworks, from a variety academic traditions (Klein and Myers 1999; Walsham 1993). One of the earliest examples of this was the sociotechnical frameworks and methodology of Land (1979) and Mumford (1995). More recently, IS has drawn on Giddens' structuration theory (Giddens 1979, 1984; Jones 1999; Jones and Karsten 2008) from sociology and the traditional actor network theory (ANT) of Latour (2005), Callon (1986), and Law $(1987,1992)$ from science studies. Continuing this tradition of drawing on external theory and deploying it within IS, this paper outlines and explores the potential of Deleuze and Guattari's rhizomatics $(1983,1996,2004)$ as an overtly postmodern ontology and analytical framework for IS interpretive studies, which also has the capacity to inform practice.

Information systems as a discipline has many development methods, with a heterogeneity of research schools, subjects, approaches and epistemologies; despite attempts to technologically ground it (Lee et al. 2001). It also shows eclecticism, practice focus, development processes, and tools, all with divergent schools of thought as a critical component. When contrasted to the "noble" sciences, such as Physics and Chemistry, IS is (to use a Deleuze and Guattari term) an "ignoble science," a post-modern pragmatics, complete with a number of divergent and competing perspectives and practices - from the managerial to the critical. This ignobility for the authors is a term of esteem rather than disapproval; even more so for IS, it is argued and explored here, when it enables a rhizomatic interpretation of an IS case study. In doing so, this paper seeks to challenge Deleuze and Guattari's own view of information or computer systems as being essentially and necessarily arboreal. Rather, to argue, that IS can also be rhizomatically critical.

These explorations start with the identification of core concepts and questions as to the relevance of rhizomatics to IS research and practice. It then proceeds to offer an interpretation, or rather a reinterpretation, of a case study surrounding the problematic introduction of an enterprise resource planning (ERP) system into a North American Ivy League University. These outcomes lead to the proposition that rhizomatics can be used to better understand information systems.

\section{RHIZOMATICS}

A rhizome

connects any point to any other point, and its traits are not necessarily linked to traits of the same nature; it brings into play very different regimes of signs, and even nonsign states... .It is composed not of units but of dimensions, or rather directions in motion. It has neither beginning nor end, but always a milieu from which it grows and which it overspills... . The Rhizome proceeds by variation, expansion, conquest, capture, offshoots....the Rhizome pertains to a map that...is always detachable, connectable, reversible, modifiable, and has multiple entryways and exits (Deleuze and Guattari 2004, p. 23). 


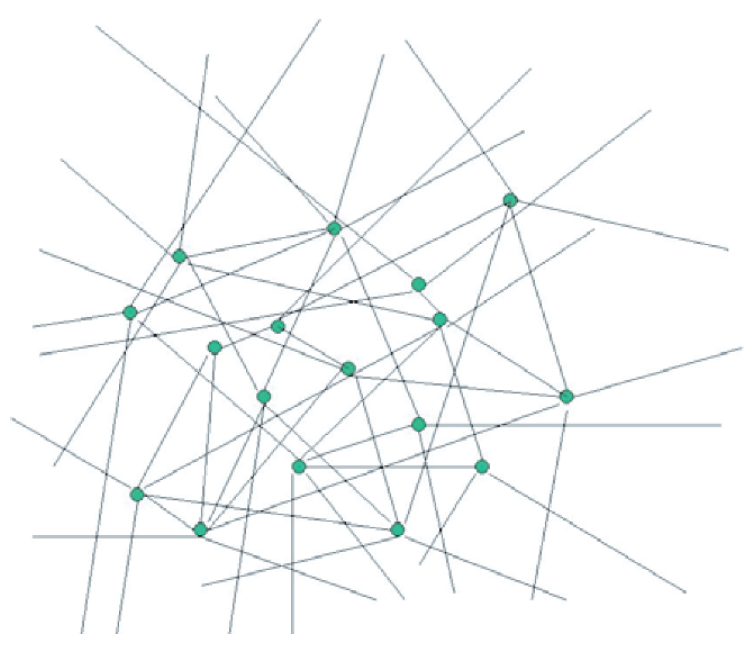

Figure 1. A Representation of the Rhizome. There is no center, but each node can link to an infinite number of other nodes (Seto 2006).

The rhizome, for Deleuze and Guattari, is a nonhierarchical network; it is root-like, spreading over space and time, growing incessantly as long as there are nutrients and energy available (see Figure 1). The rhizome has the potential to be universally ubiquitous, neither beginning nor ending; rather it spreads horizontally in all directions and across its' own self-created time and space. As an interpretive metaphor it is made up of a whole set of entities, such as human, nonhuman, and humanchines. It has no overarching governor or controller, it exhibits no intentionality, although domains within the rhizome, or plateaus, may grow, expanding ubiquitously and changing its constituents, shape, and trajectory in accordance with inherent conventions, often localized rules, and self-imposed constraints, acting within external contingencies in the wider rhizome. The rhizome is guided in its growth and spread by a set of self-governing, inherent principles and parameters both necessary to and a condition of its dynamics and autopoietic persistence (Maturana and Varela 1980). Self-delineating plateaus form within the rhizome through processes of what Deleuze and Guattari identify as territorialization. These, in turn, deconstruct through the processes of deterritorialization when constituents separate and disengage from each other, only to form anew with other constituents through processes of reterritorialization. Territorialization is the dynamic by which the rhizome grows, incorporates, ubiquitously spreads, and mutates:

A multiplicity has neither subject nor object, only determinations, magnitudes, and dimensions that cannot increase in number without the Rhizomic multiplicity also changing in nature (the laws of combination therefore increase in number as the multiplicity grows) (Deleuze and Guattari 1988, p. 8).

Seen as a landscape, the rhizome is traversed by nomads. These are dynamic, highly mobile territorializations lacking in any form of structure, "bodies without organs" 
(Deleuze and Guattari 1996; Deleuze and Guattari 2004). Nomads are dynamic localized autopoietic territorializations within the rhizome. Their migrations are achieved through processes of mapping and mutual transcription. The nomads traverse the rhizome in the way a mini-whirlpool skitters across flowing water, incorporating and ejecting water molecules as it goes, constituting bodies without organs in that they have form, made up of a locally territorialized multiplicity of constituents, without predetermined structures. Nomads are created by constituents spontaneously territorializing and deterritorializing to facilitate it traversing across the rhizome, and over time creating pathways across it.

The mechanism of territorialization, deterritorialization, and reterritorialization that create the dynamics and substance of the rhizome govern the coming together of the heterogeneity of its human and/or nonhuman constituents, their agency and their subsequent splitting up. These territorializing processes, in turn, constitute the dynamic network growth and chart its trajectory across time and space.

In contrast, and in opposition to the rhizome, is the tree, the vertical arboreal structure of the state, the establishment institutions, for example, the clinical royal colleges, the academe Française, multinational corporations. Deleuze and Guattari see these as vertical hierarchical arboreal structures. Such tree-like structures seek to exert control over all that they territorialize within their own hierarchical autopoiesis (Maturana and Varela 1980), including the rhizome from which they grow. The state can be seen as arboreal structures, domains in which arboreal political parties war against each other across the wider rhizomic polity. A tree, for Deleuze and Guattari (2004), is a site of power and domination. It is controlled from the top down to the bottom. Those at the top look down on and manipulate those below, who in turn look up to them. Communication in the tree is, vertical, from top to bottom, in contrast to the rhizome, in which communication is horizontally and universally ubiquitous. From branch tip to root, a tree is a control structure that grows from a single seed. It punctures the rhizome and disfigures it, seeking to territorialize those constituents who constitute the rhizome for its ends, creating striped, striated, patterns within its smooth surface. The tree's roots spread out and further distort the smoothness of the surrounding rhizome. Trees, and those at the top of its hierarchy, also seek to territorialize those who constitute the rhizome for their own power and instrumental ends. It forms a unity of which Deleuze and Guattari say, "The notion of unity appears only when there is a power takeover in the... [Rhizomic] multiplicity... or a corresponding subjectification proceeding"(1988, pp. 8-9).

The tree, for Deleuze and Guattari, is both a sign and a signifier, representing status, command, and domination, the "tree articulates and hierarchies." They cite Rosenstiehl and Petitot's (1974) critique of the arboreal as a representation for hierarchy and repressive power. The arboreal invokes "the imagery of command trees," identifying them as centered systems or hierarchical structures, and that "accepting the primacy of hierarchical structures amounts to giving arborescent structures privileged status." For them, grand science (e.g., Physics, Chemistry), even establishment "high art," constitutes arboreal structures that are aligned with, and patronized by the state and economic elites. Equally so are the multinational corporations, which also become territorialized into government, military, and industrial arboreal complexes that emerge vertically out of the rhizome that is a country's, and indeed the world's polity. The roots of these vertical hierarchies generate striated domains within the, otherwise smooth, free flowing, rhizome. The state epitomizes the arboreal, the tree of command, but so do multinational 


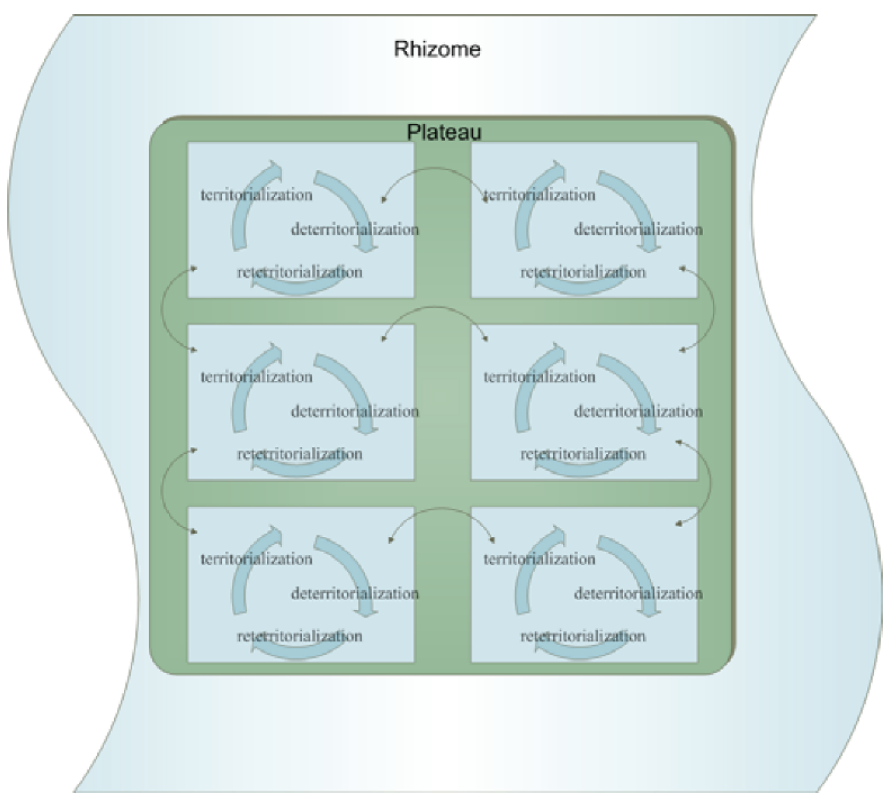

\section{Figure 2. Rhizome and Plateau Representation}

companies and, indeed, all hierarchical structures. Arboreal systems epitomize cybernetic (Ashby 1956; Wiener 1948) hierarchies, in which information, power, and control flow vertically rather than horizontally across the rhizome, centered in its plateaus. There is no one governing language within the rhizome; rather, there is a multiplicity of dialects, languages and idioms. The rhizome is truly heterogeneous in nature.

The rhizome is constituted, over time, out of an incessant myriad of instances of territorialization, deterritorialization, and reterritorialization. If many constituents territorialize together out of common interests, mutuality, interdependency, and, in some instances, the need for collaborative agency, then multiplicities of them may form a semipermanent, heterogeneous plateau within the wider rhizome (see Figure 2). Such rhizomic plateaus not only embody and exhibit the principles of the rhizome set out above, but are also delineated as persistent territorializations, forming localized assemblages of affinity within the wider rhizome. A plateau is

a continuous, self-vibrating region of intensities whose development avoids any orientation toward a culmination point or external end.... [It is also] any multiplicity connected to other multiplicities by superficial underground stems in such a way as to form or extend a Rhizome (Deleuze and Guattari 1988, p. 22).

Here, persistent self-territorialized networks of humans and nonhuman constituents form plateaus (Deleuze and Guattari 1996, 2004; see Table 1).

There are no singularities within the rhizome; all are pluralities. The subjects within the rhizome are best served by being thought of as collective individuals - what we call humanchines. However, following Deleuze and Guattari, they constitute at their most 
simplistic a body without organs. Humanchines are intersections of the human and nonhuman, which through a process of mutual territorialization constitute the contingent body without organs, without structure.

All such collectives are viewed here as self-territorializations of and by their constituents; these, in turn, are themselves rhizomic in their relationships, actions, and behaviors. Within the self-convening, self-sustaining, self-delineated rhizome, there emerges a particular form, the nomad. In "Treatise on Nomadology - The War Machine," Deleuze and Guattari (2004, Chapter 12, pp. 351-423) describe a nomad as an auto-convened, autopoietically persistent entity, one that migrates and traverses both the smooth spaces of the wider rhizome and the striated domains within it induced by their proximity to arboreal structures. It is a site of resistance and a center for forces against existing and prospective arboreal structures growing out of the rhizome. The nomad is never still, it is constantly in transition between territories within the rhizome, until, that is, they territorialize others to form part of a plateau.

Nomads convene other constituents (from within the rhizome) into a plane of consistency, an undifferentiated form with no obvious components whose self-actuating role is to challenge all seats of power that manifest themselves in the form of arboreal structures. As the nomad has no structure or fixed identity, it is a body without organs. This challenge initially occurs a striated space is encountered. Such a space is created within the rhizome by the roots of an arboreal structure spreading through the smooth rhizome; the tree is a simile for the arboreal hierarchy that is the state, but could also be an enterprise. On meeting an arboreal structure, such as an arm of the state or enterprise, the nomad, autonomically, reterritorializes itself into a war machine, whose role is to challenge not only behaviors of that arboreal state, but its very existence. The war machine is a ubiquitous feature of the rhizome's thousand plateaus.

Deleuze and Guattari decry, "The tree is already the image of the world, or the root the image of the world-tree. The tree articulates and hierarchizes tracings; tracings are like the leaves of a tree." Further, almost in exasperation, they go on, "We're tired of trees. We should stop believing in trees, roots, and radicles. They've made us suffer too much." The rhizome and the tree are in a relationship of struggle over space and across time. Nomads form within the rhizome. They are rather like rebel guerrilla bands, localized territorializations of constituents within the rhizome formed to constitute war machines. Their role is to challenge the threats and incursions of the arboreal state into the rhizome. The nomad does this by cutting off the trees roots, preventing the tree from creating distorting striped patterns within the rhizome and territorializing constituents into its vertiginous trunk. As a manifestation of this struggle, rhizomes can be observed growing out of the tree or undermining its roots, deterritorializing and reterritorializing the tree's constituents back into its plateaus. The relationship between the state tree and the rhizomic is one of incessant struggle over the territorializing, deterritorializing, and reterritorializing of their constituents

"The war machine is the invention of the nomads (insofar as it is exterior to the State apparatus and distinct from the military institution) and exists outside of the State apparatus" (Deleuze and Guattari 2004, p. 419). The smooth (nonhierarchical) spaces that nomads traverse (as revealed in Deleuze and Guattari 1996) are in conflict with the striated spaces formed within the rhizome by the arboreal state and the corporation. A rhizomic nonstriated space is formed by the rhizome, one traveled by the nomad, constitutes a plane of consistency. As such, the rhizome 
knows nothing of differences of level, orders of magnitude, or distances. It knows nothing of the difference between the artificial and the natural. It knows nothing of the distinction between contents and expressions, or that between forms and formed substances (Deleuze and Guattari 2004, p. 77).

The relationship between the rhizome and the arboreal are not mutually exclusive, they intermesh, as Deleuze and Guattari point out:

a tree branch or root division may begin to burgeon into a Rhizome. The coordinates are determined not by theoretical analyses implying universals but by a pragmatics composing multiplicities or aggregates of intensities. A new Rhizome may form in the heart of a tree, the hollow of a root, the crook of a branch. Or else it is a microscopic element of the root-tree, a radicle that gets Rhizome production going (2004, p. 15).

The capacity of rhizomatics as an extended metaphor and theoretical framework through which an informatics case study is explored in the following interpretation of the case of Ivy University.

\section{INFORMATION SYSTEMS AND THE RHIZOME: THE CASE OF IVY UNIVERSITY}

This exploration of rhizomatics is as an interpretive framework with which to enhance understanding and inform informatics interpretive research and practice (Klein and Myers 1999; Walsham 1993). This paper will employ the vocabulary of rhizomatics as an extended metaphor (Lakoff and Johnson 1980; Ricoeur 1978) throughout a narrative reporting of the case of Ivy University (Scott and Wagner 2003; Wagner and Newell 2004) as a means of both enriching and illuminating it. Following that, a brief reflection and evaluation of rhizomatics and its potential as an ignoble science is discussed. The case presented and rhizomatically analyzed here was constructed from reviewing the published papers of the studies carried out into the case of Ivy University by Wagner and Newell (2004). Direct correspondence and discourses with Wagner were also used to ensure the efficacy of this interpretation.

\subsection{A Rhizomatic Interpretation of Ivy University}

An informatics example of arboreal territorialization struggles within a rhizomic setting will be illustrated here, based on the richly exemplified exploration of the introduction of an enterprise resource planning application into a major university within the United States, which was given the aptly rhizomatic nom de guerre of Ivy (Scott and Wagner 2003; Wagner and Newell 2004). The case is set within a complex sociotechnical rhizome, a complex heterogeneity in the form of Ivy University. 
Table 1. Major Rhizomatic Concepts

\begin{tabular}{|c|c|c|}
\hline $\begin{array}{c}\text { Rhizomatic } \\
\text { Concepts }\end{array}$ & Explanation & Example (Ivy University Case) \\
\hline 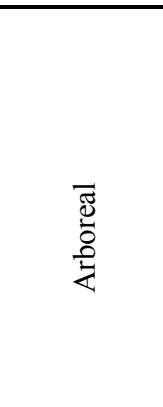 & $\begin{array}{l}\text { In contrast to, and opposing the } \\
\text { thizome, is the tree, the vertical } \\
\text { arboreal structure of the state. }\end{array}$ & $\begin{array}{l}\text { The president of Ivy University, accom- } \\
\text { panied by an important academic provost } \\
\text { together with a vice president for Finance } \\
\text { and Administration and their associated } \\
\text { central administrative infrastructure. Con- } \\
\text { trolling or even replacing departmental IS, } \\
\text { territorializing them and their departments } \\
\text { within and through an ERP that was arbor- } \\
\text { eally linked directly to the executive, com- } \\
\text { puterized IS as being a manifestation of the } \\
\text { arboreal command tree. }\end{array}$ \\
\hline $\begin{array}{l}\widehat{0} \\
\vdots \\
0 \\
0 \\
0 \\
0 \\
0 \\
0 \\
0 \\
0 \\
0 \\
0 \\
3 \\
7 \\
0 \\
0\end{array}$ & $\begin{array}{l}\text { A reflexive in-folding of the } \\
\text { social world which enables the } \\
\text { emergence of subjectivity. While } \\
\text { the BwO is the site of domination, } \\
\text { it is also the site of resistance and } \\
\text { refusal, and can be understood } \\
\text { also as a limit constituted in this } \\
\text { opposition of power and resis- } \\
\text { tance. Within this dynamic } \\
\text { struggle between domination and } \\
\text { resistance, the BwO is constructed } \\
\text { and reconstructed continually } \\
\text { (Fox 1999). }\end{array}$ & $\begin{array}{l}\text { Resulting from the dynamic struggle } \\
\text { between the powerful president (the exe- } \\
\text { cutive) and the resourceful local depart- } \\
\text { ments and their administrators. }\end{array}$ \\
\hline : & $\begin{array}{l}\text { To take the control and order } \\
\text { away from a land or place (terr- } \\
\text { itory) that is already established. } \\
\text { It is to undo what has been done; } \\
\text { the freeing of labor-power from } \\
\text { specific means of production. }\end{array}$ & $\begin{array}{l}\text { ERP had been deterritorialized from the } \\
\text { executive and reterritorialized into the } \\
\text { various plateaus of the self-territorializing } \\
\text { departments, for their own use, rather than } \\
\text { the executive's. Only in this way was there } \\
\text { departmental adoption. }\end{array}$ \\
\hline $\begin{array}{l}\tilde{\Xi} \\
\tilde{\Xi} \\
\text { Z }\end{array}$ & $\begin{array}{l}\text { Nomads may follow customary } \\
\text { paths, but the points along the } \\
\text { way possess no intrinsic signifi- } \\
\text { cance for them. They do not mark } \\
\text { out territory to be distributed } \\
\text { among people (as with sedentary } \\
\text { cultures); rather, people are distri- } \\
\text { buted in an open space without } \\
\text { borders or enclosures. Nomad } \\
\text { space is smooth, without features, } \\
\text { and in that sense the nomad tra- } \\
\text { verses without movement, the } \\
\text { land ceases to be other than sup- } \\
\text { port (Fox 1999); dynamic highly } \\
\text { mobile lacking in any form of } \\
\text { structure, bodies-without-organs. }\end{array}$ & $\begin{array}{l}\text { Resourceful administrators exported data } \\
\text { from the bolt-on and imported it into } \\
\text { Microsoft Excel enabling them to recreate } \\
\text { silos of activity, answer faculty questions } \\
\text { about funding availability, and maintain } \\
\text { their academic temporal zones. These } \\
\text { local shadow systems were shared among } \\
\text { academic departments and resulted in the } \\
\text { mobilization of a grassroots network that } \\
\text { fused Ivy's historical working rhythms } \\
\text { with ERP generated data. }\end{array}$ \\
\hline
\end{tabular}




\begin{tabular}{|c|c|c|}
\hline $\begin{array}{c}\text { Rhizomatic } \\
\text { Concepts }\end{array}$ & Explanation & Example (Ivy University Case) \\
\hline 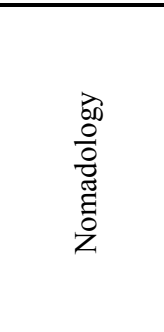 & $\begin{array}{l}\text { Multiplies narratives; creating an } \\
\text { uninterrupted flow of deterritori- } \\
\text { alization which establishes a line } \\
\text { of flight away from territories, } \\
\text { grand designs and monolithic } \\
\text { institutions, not something that is } \\
\text { achieved once and for all, there is } \\
\text { always another deterritorialization } \\
\text { (Fox 1999). }\end{array}$ & $\begin{array}{l}\text { Essentially the whole of the Ivy University } \\
\text { case, from the president's attempt to } \\
\text { introduce the ERP, to the subversive action } \\
\text { by the departments and the subsequent } \\
\text { withdrawal of the ERP and the revised } \\
\text { scenario. }\end{array}$ \\
\hline $\begin{array}{l}\vec{\Xi} \\
\frac{\Xi}{\pi} \\
\frac{\pi}{2}\end{array}$ & $\begin{array}{l}\text { "[A plateau] is always in the } \\
\text { middle, not at the beginning or the } \\
\text { end... a continuous, self-vibrating } \\
\text { region of intensities whose devel- } \\
\text { opment avoids any orientation } \\
\text { toward a culmination point or } \\
\text { external end" (Deleuze and } \\
\text { Guattari 1988, p. 22). }\end{array}$ & University departments. \\
\hline 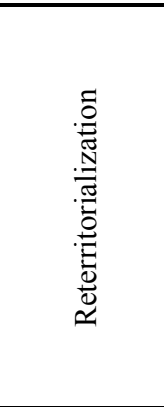 & $\begin{array}{l}\text { The restructuring of a place or } \\
\text { territory that has experienced } \\
\text { deterritorialization; it is the design } \\
\text { of the new power. }\end{array}$ & $\begin{array}{l}\text { The department administrators went about } \\
\text { reterritorializing the data the ERP captured } \\
\text { and collated and used it for themselves. } \\
\text { They then reconfigured it and used it to } \\
\text { resist the attempted arboreal territorializa- } \\
\text { tion of the departmental plateaus by the } \\
\text { executive. When buy-in to the ERP was } \\
\text { eventually achieved (2003), it was on the } \\
\text { terms of the departmental administrative } \\
\text { plateaus rather than in response to demands } \\
\text { of the arboreal central executive. }\end{array}$ \\
\hline 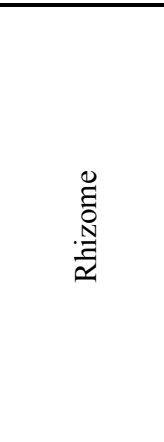 & $\begin{array}{l}\text { "[A rhizome] connects any point } \\
\text { to any other point... it brings into } \\
\text { play very different regimes of } \\
\text { signs, and even nonsign states....It } \\
\text { is composed not of units but of } \\
\text { dimensions....It has neither } \\
\text { beginning nor end, but always a } \\
\text { middle (milieu) from which it } \\
\text { grows and which it overspills....A } \\
\text { rhizome is made of plateaus" } \\
\text { (Deleuze and Guattari 1988, p. } \\
\text { 21). }\end{array}$ & $\begin{array}{l}\text { University rhizomic heterogeneity was } \\
\text { constituted out of academic and non- } \\
\text { academic staff, buildings and resources, } \\
\text { support staff, students and researchers, } \\
\text { rules and regulations, research and teaching } \\
\text { staff and teams, administration at the cen- } \\
\text { tral, faculty and departmental levels terri- } \\
\text { torializing into a multiplicity of depart- } \\
\text { mental plateaus, colleges, schools, research } \\
\text { centers, research projects and teams, and } \\
\text { undergraduates and graduates undergoing a } \\
\text { myriad of programs. }\end{array}$ \\
\hline 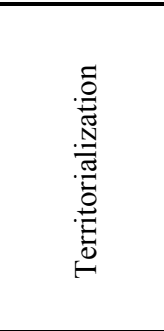 & $\begin{array}{l}\text { The outcome of dynamic relations } \\
\text { between physical and/or psycho- } \\
\text { social forces. Territorialization is } \\
\text { an active process, whose agent } \\
\text { may be human, animate, inani- } \\
\text { mate, or abstracted. }\end{array}$ & $\begin{array}{l}\text { Ivy wanted to implement an integrated } \\
\text { financial infrastructure that would unify its } \\
\text { silos of administration. There was a } \\
\text { machination of arboreal territorialization. } \\
\text { The attempted implementation of the ERP } \\
\text { was a machination of arboreal territoriali- } \\
\text { zation directed by a paternalistic VP } \\
\text { toward achieving control over all the } \\
\text { departments and their research budgets. }\end{array}$ \\
\hline
\end{tabular}




\begin{tabular}{|c|l|l|}
\hline $\begin{array}{c}\text { Rhizomatic } \\
\text { Concepts }\end{array}$ & \multicolumn{1}{|c|}{ Explanation } & \multicolumn{1}{c|}{ Example (Ivy University Case) } \\
\hline & $\begin{array}{l}\text { Challenge to the behavior and } \\
\text { existence of the arboreal state. }\end{array}$ & $\begin{array}{l}\text { The departmental administrators, in league } \\
\text { with their in-house applications and other } \\
\text { data sources, had become self-territorial- } \\
\text { ized war machines that carried on as before } \\
\text { and, where possible, aligned the Univer- } \\
\text { sity's corporate information from the new } \\
\text { ERP with their interests. Their purpose } \\
\text { was to resist and undermine the striped } \\
\text { patterns forming in the University rhizome. }\end{array}$ \\
\hline
\end{tabular}

Since the concepts involved in rhizomatics are unlikely to be that familiar, it was thought important to provide some explanation of the main concepts and examples (drawn from the Ivy University case) to illustrate them. However, it should be noted that these concepts are tightly intertwined and have been pulled apart only for analytical purposes. Still, the links are so close that some of them rely on each other for understanding.

Ivy is a large prestigious U.S. research-driven university governed by a provost and vice president along with a board of directors. The administration is centrally controlled but relatively decentralized in terms of the degree of autonomy experienced by academic departments and research teams. As such, Ivy has historically struggled with duplication and consistency of administrative activities done locally and then reported on centrally. "A decision was made in 1996 to modernize all administrative information systems through ERP software” (Wagner and Newell 2005a, p. 9).

This university rhizomic heterogeneity was constituted out of academic and nonacademic staff, buildings and resources, support staff, students and researchers, rules and regulations, research and teaching staff and teams, administration at the central, faculty, and departmental levels territorializing into a multiplicity of departmental plateaus, colleges, schools, research centers, research projects, teams, and undergraduates and graduates undergoing a myriad of programs. Collectively they constituted the rhizome that was Ivy University. Through the center of Ivy University grows the extremely powerful arboreal president, who is accompanied by an important academic provost together with a vice president for Finance and Administration and their associated central administrative infrastructure. The University itself is overseen by a "corporation" that has a similar function to a traditional board of directors.

A detailed analysis of the introduction of the ERP into Ivy University is provided by Scott and Wagner (2003) and Wagner and Newell (2004). The goal of introducing the ERP was "the achievement of order...within the University around the applications implementation and alignment of faculty and department." The intent was to explore the forms of social ordering needed to create a workable ERP.

In summer 1996, Ivy created an alliance with Vision Corporation to become their "showcase customer"...in order to develop and implement flagship technology. Ivy wanted to implement an integrated financial infrastructure that would unify its silos of administration.

There was a machination of arboreal territorialization. 
Wagner and Newell report that "the vendor's desire to work with Ivy to convert its government/public sector package into a higher education 'solution' was attractive to Ivy who wanted to be seen as an administrative leader of higher education institutions" (Wagner and Newell 2005b, p. 450). The system vendor's reason for working with Ivy in this high profile university environment was to develop and thoroughly road test an extension of their existing ERP application as a way into the United States, and potentially global, university sector. A project manager was appointed at the project inception and, in 1997, a technical director was hired to take control of the technical progress of the Ivy project. The project itself was

formed and functional teams were created with cobusiness and -technical leaders. The teams were comprised mostly of Ivy middle managers from central administration whose permanent positions had been backfilled for the duration of the project. Although an experienced ERP project manager had been hired, the real authority lay with the teams who communicated directly with Ivy's newly appointed VP for finance and administration (Wagner and Newell 2006, p. 46).

However, this centrally driven ERP initiative resulted in considerable resistance from the University's multiple departmental plateaus, including not only the departmental administrators but also their staff and their in-house developed, or procured, administrative information systems. The new ERP information technology was viewed as an arboreal machination of control and incorporation, an attempt to bring the faculty and departments under the control of the vice president. This managerial arborealization by the budget director, acting on behalf of Ivy" administration necessitated that the "day-today leadership of the initiative was driven by the VP's core group of middle managers, the majority of whom were considered functional business experts with only a cursory understanding of ERP technology" (Wagner and Scott 2001, p. 10).

The ERP was, from a rhizomic perspective, a panoptical device for attaining informational and organizational arborealization, part of the creation of a managerial command tree whose controlling roots, if allowed, would span the University rhizome. It would, as Scott and Wagner report, encompass not only the technology but centralize control over the departmental plateaus along with their faculty and support staff so that they could be managed centrally (i.e., arboreally) by the administration within a corporate hierarchical tree formation. As the budget director, acting on behalf of the administration's interests, says,

mentality that we've had...for managing is primitive to say the best and it's very old-fashioned...the corporate world left it many years ago....Many faculty...think of things fundamentally wrong...we want to move people towards a management model where we're going to ask [them] to put together a time-phased business plan (Scott and Wagner 2003, p. 305).

This executive and managerial call for a business plan from each department was a further machination for asserting the University administration's corporate arboreal control over the rhizomic University plateau of departments out of which it had grown and over which it sought dominion. The departmental business plans, their subsidiary status 
and intended integration within the University executive's overall business plan were a further attempt at the arborealization of the University departments. In a similar way, the attempted implementation of the ERP was a machination of arboreal territorialization directed by a paternalistic vice president toward achieving control over all the departments and their research budgets that had been territorialized locally within the departments through a principle of mutuality to form the wider rhizome that was Ivy University.

The intended role for the ERP actor was being created by the supplier on behalf of the vice president. It was one of controlling or even replacing departmental IS, territorializing them and the departments within and through an ERP that was arboreally linked directly to the executive. The process was one in which ERP information resonated with Deleuze and Guattari's (2004) view of computerized IS being a manifestation of the arboreal command tree. The ERP being implemented here was a machination by the executive of departmental arboreal territorialization with little reciprocity.

However, by 1998, the project was in crisis. There was considerable resistance to it from the departments and their administrators and the vice president challenged Vision on this matter. A new ERP module specifically for the university market was being developed to address this issue at the end of 1998. It was intended to be a means, by the executive, of territorialization, subsuming local departmental control over research project financial information and management, the applications on which they ran, and its data. The move by the executive to territorialize and control research budgets was a means of arboreally centralizing control over them by the administrative trunk of Ivy. This entailed the ERP provider, who had never encountered such academic environments before, in developing new modules to meet the requirements of what until now had been an untapped market. It was this opportunity that attracted them to the Ivy project in the first place. The project afforded the company with an opportunity to develop and road test modifications within the academic market to their existing ERP product and services. The core of this was to develop a new module for their ERP specifically to meet the needs of the university market.

The ERP (see Figure 3) went live and, by July 1999, it was collating and delivering data to the departments. However, it was not successful at being a machination of arboreal territorialization. The data it collected and collated, while timely and available, was not of the categories and qualities that were meaningful to the departments and their administrators under the new conditions within Ivy. The ERP had, therefore, failed to become part of Ivy's departments. As a machination of arborealization it was a failure. The departments, in the summer of 1999, revolted at what they saw as an attempted arboreal territorialization of them and their information by the arboreal executive.

In this legacy environment, a great deal of power remained within departmental units whose administrators used shadow systems to help them translate between academic/programmatic needs and institutional reporting requirements, whereas in the ERP-enabled environment these administrators were required to work within a system designed to meet central administrative needs. What was previously a relatively straightforward accounting system was made complex, nonintuitive and difficult from a departmental perspective. This lead to a prominent controversy at Ivy that nearly stalled the use of the ERP by the academic constituency because they felt their needs were not considered in its design (Wagner and Newell, 2005a, pp. 22-23). 


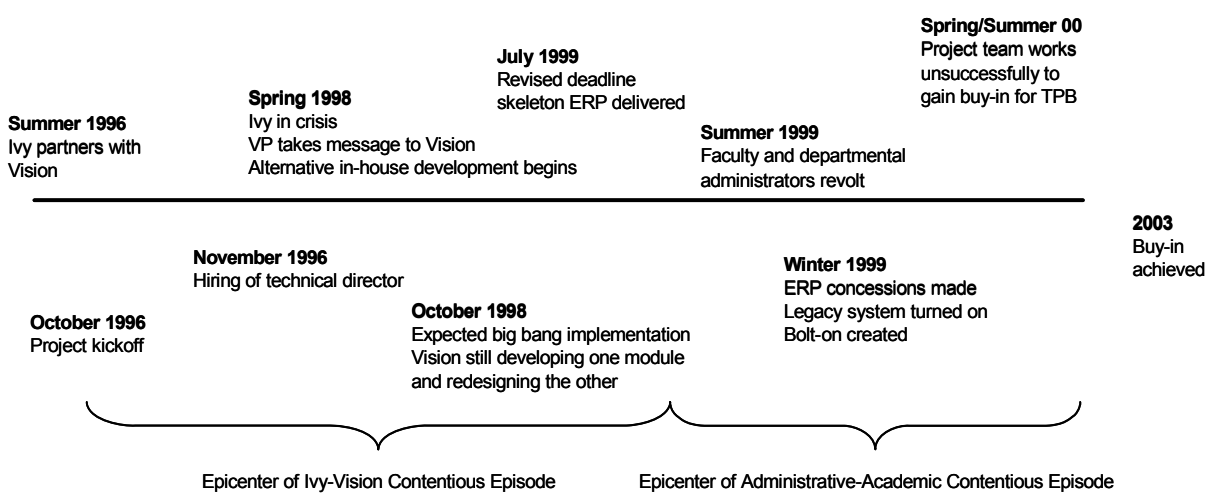

\section{Figure 3. Timeline of Ivy ERP Project Highlighting Contentious Episodes (after Wagner and Newell 2005b)}

As this attempt at arborealization, by trying to bring the departments and their IS into the executives arboreal plan, was thwarted concessions were made and the new module was never fully finalized or implemented. The departments and their local administrators resisted the vice president's machination of arborealization through the ERP. This was intended to be achieved by imprinting a hierarchical arboreal model into the ERP and onto the departmental plateaus formed within the wider University rhizome, over which the central administration would, via the ERP, have dominion. Instead, the departmental plateaus retained the territorialization of their own IS for themselves. In doing so, they maintained their own autonomy, as plateaus, within the wider rhizome of the University's collegiate plateau. The ERP providers, in 1999, failed to develop fully a university "bolton" module that would have overtly territorialized the various departmental plateaus' own IS into the central administration's ERP. This in turn afforded them with a means of managing the departments' operations, finances, and personnel related to research grants and projects by the central, arboreal, administration.

The department administrators went about reterritorializing the data the ERP captured and collated and used it for themselves. They then reconfigured it and used it to resist the attempted arboreal territorialization of the departmental plateaus by the executive. As Scott and Wagner reported from Spring/Summer 2000,

The "bolt on" remained unused by administrators who conscripted actors from their past and present (e.g., legacy reports, spreadsheet tools, faculty advocates) in order to create an alternative to the ERP system. In this way they were trying to actively redefine the future of Ivy's administrative environment. Resourceful administrators exported data from the bolt-on and imported it into Microsoft Excel enabling them to recreate silos of activity, answer faculty questions about funding availability, and maintain their academic temporal zones. These local shadow systems were shared among academic departments and resulted in the mobilization of a grassroots network that fused Ivy's historical working rhythms with ERP generated data (Scott and Wagner 2003, p. 306). 
In rhizomatic terms they reterritorialized informational actors from a myriad of sources to enable them to persist and function as a plateau within the wider Ivy rhizome.

The corporate executive suboptimal roll-out of the ERP reports "was complicated by user resistance to the grants and contracts module design. The academic constituencies who had expectations of an improved working environment were unable to complete crucial administrative tasks" (Wagner and Newell 2006, p. 46). Faculty members demanded changes in the ERP's design as well. Once implemented it was intended that the ERP application would either effectively replicate the existing arboreal organization and/or force the organization to replicate the arboreal structures inscribed in the ERP, or both. Information would flow from the departments up the arboreal ERP and instructions and corporate information from the executive would flow down it to the departments. The ERP and its developer betrayed the intentions of the executive.

Rhizomatically, the departmental administrators, in league with their in-house applications and other data sources, had become self-territorialized war machines that carried on as before and where possible aligned the University's corporate information from the new ERP with their interests. Their purpose was to resist and undermine the striped patterns forming in the University rhizome and its departmental plateaus as result of the arboreal ambitions of the executive and its vice president. The local administrators and their departmental plateaus had, by 2002, turned the tables on the executive's arboreal ERP. The administrators territorialized the ERP academic module for themselves. The departments also territorialized and used the data the ERP produced, not for what was intended by the executive, but for their own purposes, and integrated it with the data from their own information systems and sources and carried on independently. In this sense there was, by 2003, some buy in but it was on these departmental administrators' own terms. The executive, it appears, had put themselves "up a tree" with the ERP. It could be said the executive was mistaken in introducing the ERP into the University plateau in the first place.

When buy-in to the ERP was eventually achieved (2003), it was on the terms of the departmental administrative plateaus rather than in response to demands of the arboreal central executive; as Wagner and Newell report, "While it was possible for the project team to move forward during implementation by using hierarchical power to impose a particular decision, this did not lead to a successful ERP system in-use (2005a, p. 23). As a machination of arborealization by the executive of the departmental plateaus of the Ivy University's rhizome, the ERP failed. Rhizomatically what was happening in Ivy between the centered departmental plateaus and their nomadic administrator/local data systems and the arboreal University executive and its ERP was, as Deleuze and Guattari succinctly capture was an attempt at the

arborification of multiplicities....[which] occurs when the stems form segments that striate space in all directions, rendering it comparable, divisible, homogeneous...conversely, and without symmetry, the stems of the Rhizome are always taking leave of the trees, the masses and flows are constantly escaping... a whole smoothing of space, which in turn reacts back upon striated space (1988, p. 557).

By using their own data sources to initially react to and resist central arborealization and then demanding on their own terms, and not the executive's, a new ERP departmental 
administration module was developed to support what the administrators did in their departmental plateaus, allowing the departmental administrators to territorialize the ERP on their own terms. Buy-in, by the administrative war machines, was achieved in 2003, but this was at a price of it being on the departmental terms and not those of the vice president and the centralized administration.

The overall result was that the vice president moved to another university with a few of his core team remaining as full-time project employees. The vice president saw the ERP become a naturalized object, part of the furniture (i.e., territorialized). But, it is argued here, only as part of an idiosyncratic community that was the University rhizome and its departmental plateaus. In rhizomatic terms the ERP had been deterritorialized from the executive and reterritorialized into the various plateaus of the self-territorializing departments, for their own use, rather than the executive's. Only in this way was there departmental adoption. The University had once again reasserted its rhizomic nature. It had resisted the arboreal territorialize of the power alliance of the executive and the ERP and restored itself to its true character as a self sustaining plurality punctuated by an arboreal administration. In Deleuze and Guattari's terms, it became a multidepartmental, self-territorializing series of plateau, a rhizomatic body without organs: "The body without organs is not a dead body, but a living body all the more alive and teeming once it has blown apart the organism and its organization....Lice hopping on the beach. Skin colonies.... The full body without organs is a body populated by multiplicities" (2004, p. 34) and, it might be said here, informated too.

Rhizomatics has been deployed here as an extended metaphor to provide interpretive insight into the Ivy narrative. In so doing, the paper has tested out rhizomatics as an interpretive framework for appreciating the nature and complexities of information systems. It also challenges Deleuze and Guattari's opinion that information systems and associated technologies can only be arboreal and centralist in nature.

The next section examines the set of principles that underpin rhizomatics. It explores the utility of these rhizomatic principles in providing a further interpretive, and more structured, tool with which to explore instances of real world informatics cases, in this instance, of Ivy.

\subsection{Interpreting Rhizomatic Principles in the Context of Information Systems}

Rhizomatic has been used, until this juncture, as an extended metaphor with which to interpretively explore and enrich the narrative of the Ivy University. Deleuze and Guattari, however, also set down a series of rhizomatic principles, essentially, properties of the rhizome. These principles can generate a series of rhizomatic questions with the potential to explore further about Ivy and its complex relationship with IS. We will considering each rhizomatic principle in turn.

\subsubsection{Principles 1 and 2: Connection and Heterogeneity}

Connectivity is seen as "the capacity to aggregate by making connections at any point on and within itself"; heterogeneity is seen as "the capacity to connect anything 
with anything other, the linking of unlike elements" (http://capitalismandschizophrenia. org/index.php/Rhizome).

Can IS be seen as network heterogeneities, integrations of humans and nonhumans and as a result rhizomic in nature? In the Ivy case, the technological IS was implemented as an attempt by the executive at arborealization, to territorialize the departmental plateaus in line with their corporate interests. However the wider Ivy rhizome, with its heterogeneity of human and nonhuman actors, their connections, and self installed inhouse IS, resisted this to the point where they reasserted their autonomy.

Can, IS alternatively be viewed as a machination of territorialization, linking other human and nonhuman constituents across the rhizome? The executive and the introduction of the ERP was a corporate machination of territorialization. The arboreal roots of an executive sought to bring central corporate governance to the rhizomic Ivy University. Buy-in to the ERP application only occurred when there was localization and departmental territorialization of the IS across the University, a suboptimal use of the new ERP.

\subsubsection{Principle 3: Multiplicity}

Multiplicity consists of "multiple singularities synthesized into a 'whole' by relations of exteriority" (http://capitalismandschizophrenia.org/index.php/Rhizome).

What are the ramifications of the rhizomic concept of multiplicity and heterogeneity for the development and creation of IS and the many forms they take? From the case of Ivy, it can be seen that the ramifications of the rhizomic concept of multiplicity and heterogeneity were ignored initially by the corporate executive and this was replicated within the arboreal nature of the ERP they procured and its suppliers provided. The multiplicity concept may be ignored in command/control tree corporate environments, where data flows up and down its trunk. However in contexts such as Ivy, where there are multiple stakeholders, individuals, groups, and organizations forming self-organizing plateaus, with localized power, multiplicity has to be included both when designing the technology and implementing the system. An ERP has an arboreal image inscribed in it, while the administrators and the IS of Ivy's multiple departments were localized territorializations. It was only when localized modules and functionality, which could accommodate to the multiplicity of departmental plateaus, and the ERP became more rhizomic and less arboreal that it was finally adopted.

\subsubsection{Principle 4: Asignifying Rupture}

Asignifying rupture refers to "not becoming any less of a Rhizome when being severely ruptured. It is the ability to allow a system to function and even flourish despite local 'breakdowns,' thanks to deterritorialising and reterritorialising processes" (http:// capitalismandschizophrenia.org/index.php/Rhizome).

Do human social and/or informated socio-technical systems exhibit rhizomic asignifying properties? In the case of Ivy, the introduction of the corporate ERP was an attempt to arboreally punctuate and control the Ivy University rhizome from the center. The aim of the executive's introduction of the ERP was to prevent Ivy University depart- 
mental plateaus from territorializing the research funding and operational resources so as to control them. However, the departments and their administrators simply drew on their own localized shadow accounting systems to circumvent the arboreal ambitions of the executive. The University rhizome, wherever there was an attempt by the executive to punctuate it, reasserted itself and fought on.

\subsubsection{Principles 5 and 6: Cartography and Decalcomania}

Cartography can be described as "the method of mapping for orientation from any point of entry within a 'whole,' rather than by the method of tracing that re-presents an a priori path, base structure or genetic axis"; decalcomania forms "through continuous negotiation with its context, constantly adapting by experimentation, thus performing a non-symmetrical active resistance against rigid organization and restriction” (http:// capitalismandschizophrenia.org/index.php/Rhizome).

Can information technologies/systems and their human partners be considered as nomads capable of creating informational pathways traversing across the wider sociotechnical rhizome? The administrators of the local departmental plateaus, along with their accounting shadow systems, clearly found ways of nomadically traversing Ivy's rhizome. This they did this to territorialize the information (from a range of sources) to maintain their independence. In addition, the departmental plateaus could manage their fiscal resources, while resisting the attempt of the centre to arborialize them. This was achieved without the ERP system's attempted arboreal territorialization. They became war machines convened out of the Ivy rhizome to challenge the legitimacy of the arboreal executive to arboreally territorialize them.

Can IS design, development or procurement, and implementation into the social or organisational rhizome be viewed as instances of cartography and decalcomania? The introduction of the ERP into Ivy University can be seen as attempted decalcomania. It was one of taking the arboreal image of the organization, which was cartographically inscribed in the ERP during its implementation processes, and imprinting it onto Ivy University and its departmental plateaus. Unfortunately, the arboreal cartography built into the ERP application, and even its special bolt on for Universities, did not map onto the Ivy rhizomatic network. As a process of decalcomania, of inscribing the arboreal image of the organization built into the ERP onto Ivy University, it failed. Some attempts at cartographical adjustment, in the form of the bolt-on module, did provide better results. However, the individual departmental administrators had far better maps with which to traverse the Ivy rhizome and create pathways in it to access the information they needed to circumvent and subvert central executive's attempt at an arboreal take-over of the whole rhizome.

\section{CONCLUSION}

In these explorations of rhizomatic informatics it has been posited that the work of Deleuze and Guattari has the potential to be an interpretive framework for the understanding of the nature of information systems and its associated practices as they occur in the real world. The concept of the rhizome and its arboreal foe, it is argued, provides 
a means not only of conceptualizing IS within social and organizational settings but offers a set of questioning principles on which the concept of a rhizomatic informatics may be based and IS case studies interpreted.

In juxtaposing the totalizing notion of the arboreal power tree to that of the heterogeneity of the ehizome, with its multiplicity of plateaus and trajectories, rhizomatics offers an image of information systems that are not solely linked to corporate needs. Rather, as argued and illustrated here through the Ivy University case, it constitutes a potential with which to underpin a more open and accessible form of IS interpretive research and participatory practices, under the ubiquitous concept of rhizomatic informatics. Specifically, the organic nature of some IS lend themselves to be seen as rhizomatic in nature (e.g., the Internet). In addition, the dynamic element inherent in the theory can also be key in understanding the developments in specific IS — not just where the IS starts, and what intentions are instantiated during the design and development, but how it develops through use over time and what trajectory is seen (cf. the technology-inpractice concept, Orlikowski 2000).

Looking at the specific issues raised by the rhizomatic principles, we can say

- IS can be seen as rhizomatic in nature (i.e., as network heterogeneities, integrating humans and nonhumans).

- IS can also be viewed as a machination of territorialization, linking other human and nonhuman constituents across the rhizome.

- Multiplicity has to be included both when designing the technology and implementing the system, or the rhizomatic properties of the organization may work against the effectiveness of the IS.

- Human social and informated socio-technical systems do exhibit rhizomatic asignifying properties, in that they are endlessly flexible and often able to reassert themselves in the face of attack and disruption.

- Information systems and technologies and their human partners can be considered as nomads capable of creating informational pathways traversing across the wider socio-technical rhizome. Again, this needs to be considered during design and development.

- IS design, development or procurement, and implementation into the organizational rhizome can be viewed as instances of cartography and decalcomania. If the new or revised information system is seen as attacking the existing rhizomatic stability (shaky at best anyway), then the war machine swings into operation and the guerilla resistance might begin. The implications for change management are significant, with sufficient time and energy needing to be allocated to this process.

These ideas also question Deleuze and Guattari's own view of computerized information systems as characterized as being purely instruments of corporate arboreal control. Rather, information technologies and data sources can be territorialized equally into, and become a constituent within, the Rhizome and the plateaus that emerge from it.

The rhizomatic principles of Deleuze and Guattari have been used here in two ways. First, they have been used as an extended metaphor, a way to enrich the case narrative of Ivy University and its ERP implementation. Second, the formal principles of rhizomatics and the questions they pose for and reveal about the nature of information systems have also been explored, through their application to the Ivy case study. Both suggest 
that rhizomatics offers an interpretive framework for the understanding of the nature and complexities of information-rich real-world contexts and a means of informing practice.

\section{Acknowledgments}

The authors wish to acknowledge the insightful and critically constructive comments of Dr. Erica Wagner with respect to the whole of this paper and in particular to those sections relating to the case study of Ivy University. We also greatly appreciate her giving us specific consent to use the case of Ivy University reported here.

\section{References}

Ashby, W. R. 1956. An Introduction to Cybernetics, London: Chapman \& Hall.

Callon, M. 1986. "Some Elements of a Sociology of Translation: Domestication of the Scallops and the Fishermen of Saint Brieuc Bay," in Power Action and Belief: A New Sociology of KNowlege?, J. Law (ed.), London: Routledge and Kegan Paul, pp. 196-233.

Deleuze, G., and Guattari, F. 1983. Anti-Oedipus: Ccapitalism and Schizophrenia, London: Athlone.

Deleuze, G., and Guattari, F. 1988. A Thousand Plateaus: Capitalism and Schizophrenia, London: Athlone.

Deleuze, G., and Guattari, F. 1996. Nomadology: The war machine, New York: Semiotexte.

Deleuze, G., and Guattari, F. 2004. A Thousand Plateaus: Capitalism and Schizophrenia, London: Continuum.

Fox, N. 1999. "Nomadology," Nick on the Web (http://www.wisdomnet.co.uk/nick/nomad.html).

Giddens, A. 1979. Central Problems in Social Theory, Basingstoke, UK: Macmillan.

Giddens, A. 1984. The Constitution of Society: Extracts and Annotations, Berkeley, CA: University of California Press.

Jones, M. 1999. “Structuration Theory," in Rethinking Management Information Systems, W. L. Currie and R. Galliers (eds.), Oxford, UK: Oxford University Press.

Jones, M. R., and Karsten, H. 2008. "Giddens's Structuration Theory and Information Systems Research,” MIS Quarterly (32:1), pp. 127-157.

Klein, H. K., and Myers, M. D. 1999. "A Set of Principles for Conducting and Evaluating Interpretive Field Studies in Information Systems,” MIS Quarterly (23:1), pp. 67-93.

Lakoff, G., and Johnson, M. 1980. Metaphors We Live By, Chicago: University of Chicago Press.

Land, F. 1979. "Organisational Problems of Implementing Distributed Systems, in Infotech State of the Art 1979 Report," Distributed Systems (2), pp. 113-121.

Latour, B. 2005. Reassembling the Social: An Introduction to Actor-Network Theory, New York: Oxford University Press.

Law, J. 1987. "Technology and Heterogeneous Engineering: The Case of the Portuguese Expansion," in The Social Construction of Technical Systems: New Directions in the Sociology and History of Technology, W. E. Bijker, T. P., Hughes, and T. Pinch (eds.), Cambridge, MA: MIT Press, pp. 111-134.

Law, J. 1992. "Notes on the Theory of the Actor-Network: Ordering, Strategy and Heterogeneity." Systems Practice (5:4), pp. 379-393.

Lee, A. S. Zmud, R., Robey, D., Watson, R., Zigurs, I., Wei, K. K., Myers, M., Sambamurthy, V., Webster, J., and Agarwal, R. 2001. "Research in Information Systems: What We Haven't Learned," MIS Quarterly (25:4), pp. v-xv.

Maturana, H. R., and Varela, F. J. 1980. Autopoiesis and Cognition: The Realization of the Living, Dordrecht, Holland: D. Reidel Publishing Company. 
Mumford, E. 1995. Effective Systems Design and Requirements Analysis: The ETHICS Approach, Basingstoke, UK: Macmillan.

Orlikowski, W. 2000. "Using Technology and Constituting Structures: A Practice Lens for Studying Technology in Organizations," Organization Science (11:4), pp. 404-428.

Ricoeur, P. 1978. The Rule of Metaphor: The Creation of Meaning in Language, London: Routledge.

Rosenthiehl, P., and Petitot, J. 1974. "Automate a social et systèmes acentrés," Communications (22), pp. 45-62.

Scott, S. V., and Wagner, E. L. 2003. "Networks, Negotiations, and New Times: The Implementation of Enterprise Resource Planning into an Academic Administration," Information and Organization (13:4), pp. 285-313.

Seto, I. 2006. "Organization of Knowledge and the Hyperlink: Eco's The Name of the Rose and Borges' The Library of Babel," Library Student Journal, November (http://www. librarystudentjournal.org/index.php/lsj/article/view/34/36).

Wagner, E. L., and Newell, S. 2004. "“Best' for Whom?: The Tension between 'Best Practice' ERP Packages and the Diverse Epistemic Cultures of Diverse University Context," Journal of Strategic Information Systems (13:4), pp. 305-328.

Wagner, E. L., and Newell, S. 2005a. "Making Software Work: Problem Solving a Troubled ERP Implementation," CHR Working Paper Series Center for Hospitality Research, Cornell University.

Wagner, E. L., and Newell, S. 2005b. "Making Software Work: Producing Social Order Via Problem Solving in a Troubled ERP Implementation," in Proceedings of the $26^{\text {th }}$ International Conference on Information Systems, D. Avison, D. Galletta, and J. I. DeGross (eds.), Las Vegas, December 11-14, pp. 447-458.

Wagner, E. L., and Newell, S. 2006. "Repairing ERP: Producing Social Order to Create a Working Information System," Journal of Applied Behavioral Science (42:1), pp. 40-57.

Wagner, E. L., and Scott, S. V. 2001. "Unfolding New Times: The Implementation of Enterprise Resource Planning into an Academic Administration," Working Paper Series \#98, Department of Information Systems, London School of Economics.

Walsham, G. 1993. Interpreting Information Systems in Organizations, Chichester, UK: Wiley. Wiener, N. 1948. Cybernetics: or Control and Communication in the Animal and the Machine $\left(2^{\text {nd }}\right.$ ed. $)$, Cambridge, MA: MIT Press.

\section{About the Authors}

Chris Atkinson is a senior lecturer in Information Systems in the Manchester Business School. Until recently he was in the UMIST School of Informatics and prior to that with Brunel University's Department of Information Systems and Computing. Originally a civil engineer, he undertook an M.Sc. and read for a Ph.D. at Lancaster University under Professor Peter Checkland in soft systems with a particular focus on systemic metaphor and its role in organizational problem solving. He has worked as an academic, consultant, and practitioner, focusing on how to integrate information systems development and organizational change, especially within healthcare settings. To that end, he has evolved and deployed the Soft Information Systems and Technologies Methodology (SISTeM). Callon and Latour's actor-network theory, along with other theories such as Deleuze and Guattari's rhizomatics and Bakhtine's carnival have recently emerged as important frameworks for his IS research, practice, and methodological development. Integrating structuration theory with ANT to create the theoretical hybrid StructurANTion has also proved fruitful as a further area for research and development. His field of study and practice has centered on working with multi-professional teams, clinicians, managers, and information systems practitioners in effecting integrated organizational development. Chris may be contacted at Christopher. Atkinson@manchester.ac.uk. 
Laurence Brooks is a lecturer in the Department of Information Systems and Computing at Brunel University, UK. He previously was a lecturer in the Department of Computer Science at the University of York and before that held a research post at the Judge Business School, University of Cambridge. He gained a Ph.D. in Industrial Management from the University of Liverpool and a B.Sc. in Psychology from the University of Bristol. His research interests focus on how IS and organizations can better fit together and create more positive outcomes. To that end, he has focused on the role that social theory (such as structuration theory, actor network theory, StructurANTion theory) might play in contributing to our understanding of information systems in areas such as health information systems and collaborative work support systems. Other research interests include early requirements engineering, the use of cognitive mapping for creating insights into complex scenarios, and exploring the role of culture in IS development and use. He is the current President of the UK Academy for Information Systems (UKAIS) and has co-chaired their last two annual conferences. Laurence can be reached at Laurence.Brooks@, brunel.ac.uk. 